\title{
Upstream process optimization and micro- and macrocarrier screening for large-scale production of the oncolytic $\mathrm{H}-1$ protoparvovirus
}

\author{
Daniel Wohlfarth ${ }^{1} \cdot$ Veronika Frehtman $^{1} \cdot$ Marcus Müller $^{1} \cdot$ Martin Vogel $^{1} \cdot$ Linh Minh Phuc Phan $^{1}$. \\ Adrian Brunecker ${ }^{1} \cdot$ Barbara Leuchs $^{1}$ (i)
}

Received: 27 May 2021 / Revised: 6 October 2021 / Accepted: 10 October 2021 / Published online: 16 November 2021

(c) The Author(s) 2021

\begin{abstract}
The oncolytic virus H-1PV is a promising candidate for various cancer treatments. Therefore, production process needs to be optimized and scaled up for future market release. Currently, the virus is produced with minimum essential medium in 10-layer CellSTACK ${ }^{\circledR}$ chambers with limited scalability, requiring a minimum seeding density of $7.9 \mathrm{E} 3 \mathrm{cells} / \mathrm{cm}^{2}$. Production also requires a 5\% fetal bovine serum (FBS) supplementation and has a virus yield up to 3.1E7 plaque-forming units $(\mathrm{PFU}) / \mathrm{cm}^{2}$. Using the animal-free cell culture medium VP-SFM ${ }^{\mathrm{TM}}$ and a new feeding strategy, we demonstrate a yield boost by a mean of $0.3 \mathrm{log}$ while reducing seeding density to $5.0 \mathrm{E} 3 \mathrm{cell} / \mathrm{s} / \mathrm{cm}^{2}$ and cutting FBS supplementation by up to $40 \%$ during the production process. Additionally, FBS is completely removed at the time of harvest. Eleven commercial micro- and macrocarriers were screened regarding cell growth, bead-to-bead transfer capability, and virus yield. We present a proofof-concept study for producing H-1PV on a large scale with the microcarrier Cytodex ${ }^{\circledR} 1$ in suspension and a macrocarrier for a fixed-bed iCELLis ${ }^{\circledR}$ bioreactor. A carrier-based H-1PV production process combined with an optimized cell culture medium and feeding strategy can facilitate future upscaling to industrial-scale production.
\end{abstract}

\section{Key points}

- Virus yield increase and FBS-free harvest after switching to cell culture medium VP-SFM ${ }^{\mathrm{TM}}$.

- We screened carriers for cell growth, bead-to-bead transfer capability, and H-1PV yield.

- High virus yield is achieved with Cytodex 1 and macrocarrier for iCellis® in Erlenmeyer flasks.

Keywords Protoparvovirus H-1PV production · Scale-up · Serum-free $\cdot$ Bead-to-bead transfer $\cdot$ Microcarrier $\cdot$ Macrocarrier

\section{Introduction}

According to the World Health Organization (WHO), cancer was the second leading cause of death worldwide in 2018, with an estimated 9.6 million deaths. The economic damage associated with cancer is significant and increasing, totaling approximately $\$ 1.16$ trillion in 2010 alone (Stewart and Wild, 2014). Oncolytic virus (OV) therapy represents a promising approach to treating this disease. OVs are genetically engineered or naturally occurring viruses that selectively destroy cancer cells without harming healthy tissue (Fukuhara et al., 2016). In 2015, the first OV therapeutic

Barbara Leuchs

B.Leuchs@dkfz.de

1 German Cancer Research Center, Tumor Virology F010, Im Neuenheimer Feld 280, 69120 Heidelberg, Germany
(T-VEC or Imlygic ${ }^{\mathrm{TM}}$ ) was approved by the Food and Drug Administration (FDA) (https://www.fda.gov/vaccines-bloodbiologics/cellular-gene-therapy-products/imlygic-talimogenelaherparepvec) and followed by the European Medicines Agency (EMA) (https://www.ema.europa.eu/en/medicines/ human/EPAR/imlygic). Other OV therapeutics based on different virus platforms (https://webs.iiitd.edu.in/raghava/ ovirustdb/clinical.php) are also in the development pipeline.

The OV drug ParvOryx utilizes the wild-type parvovirus $\mathrm{H}-1 \mathrm{PV}$, which belongs to the genus Protoparvovirus (Cotmore et al., 2014). It demonstrated oncolytic and oncosuppressive properties during preclinical proof-of-concept studies in various cultured cell lines, and in animal (Rommelaere et al., 2010; Nuesch et al., 2012) and xenograft models against several human tumor species (Geletneky et al., 2010; Faisst et al., 1998; Angelova et al., 2009a,b; Dupressoir et al., 1989). H-1PV also showed safety and immunogenic activity in clinical phase I/ 
IIa studies (Geletneky et al., 2012, Geletneky et al., 2017) and phase II studies (Hajda et al., 2021). Considering a market release of $\mathrm{H}-1 \mathrm{PV}$ in the future, the production capacity must be increased and the process optimized.

In general, an ideal bioprocess for producing biologics uses a suspension cell line to facilitate scalability and chemically defined, animal component-free cell culture media to avoid challenges concerning lot-to-lot variation, animal welfare, supply, cost, and potential regulatory restrictions in the future. However, the scalability of the established H-1PV production process is limited because it uses an adherent human cell line, with most of the generated virus being cell-associated at harvest. Additionally, little effort has been invested to render the process free of animal components. The currently employed process was established with minimum essential medium with 5\% fetal bovine serum (FBS) in stationary culture using 10-layer CellSTACK ${ }^{\circledR}$ chambers (Corning, Kennebunk, USA). We were able to significantly reduce the amount of FBS needed, ultimately resulting in FBS-free virus harvest and a higher yield, by adapting and optimizing the culture medium VP-SFM ${ }^{\mathrm{TM}}$ with a new feeding strategy. Additionally, we conducted a scale-up proof-of-concept study to produce $\mathrm{H}-1 \mathrm{PV}$ with different types of microcarriers and macrocarriers for respective use in suspension or a fixed bed. Highest virus yield was achieved with Cytodex ${ }^{\circledR} 1$ (Cytiva, Uppsala, Sweden) and macrocarrier from iCELLis ${ }^{\circledR}$ (Pall, Hoegaarden, Belgium). The application of VP-SFM ${ }^{\mathrm{TM}}$ in combination with the demonstrated feeding strategy was tested in iCELLis $®$ nano benchtop bioreactor for upscaling production to iCELLis ${ }^{\circledR} 500$.

\section{Material and methods}

\section{Cell line and cell culture media}

NB-324 K human newborn kidney cells (Tattersall and Bratton, 1983) transformed with simian virus 40 were cultured at $37^{\circ} \mathrm{C}$ either in minimum essential medium (MEM, Sigma, Steinheim am Albuch, Germany) with $0 \%$ or $5 \%$ heat-inactivated fetal bovine serum (FBS, Biowest, Nuaille, France) or VP-SFM ${ }^{\mathrm{TM}}$ medium (Thermo Fisher, New York, USA) with $0 \%, 1 \%, 2 \%$, or $5 \%$ FBS in a $5 \% \mathrm{CO}_{2}$ atmosphere. The cells were previously negatively tested for mycoplasma (Multiplexion GmbH, Heidelberg, Germany). Cell culture media were supplemented with $100 \mathrm{U} / \mathrm{ml}$ penicillin, $100 \mu \mathrm{g} / \mathrm{ml}$ streptomycin, and $2 \mathrm{mM}$ or $5 \mathrm{mM}$ L-glutamine (Thermo Fisher, New York, USA) for MEM and $4 \mathrm{mM}$ or $6 \mathrm{mM}$ L-glutamine for VP-SFM ${ }^{\mathrm{TM}}$, respectively (Supplemental Table S1).

\section{Direct and indirect cell counting and cell growth assay}

For cell counting with trypan blue, the cell culture medium was removed, and the cell layer or carriers were washed with phosphate-buffered saline (PBS), trypsinated with approximately $0.017 \mathrm{ml} / \mathrm{cm}^{2} \mathrm{PBS} / 1 \mathrm{mM}$ ethylenediaminetetraacetic acid (EDTA) $0.25 \%$ trypsin (Gibco, Grand Island, USA) at $37^{\circ} \mathrm{C}$ until full cell detachment was observed by microscope. Trypsination was stopped with $5 \%$ FBS-supplemented cell culture medium. Then, $5 \mu \mathrm{l}$ of cell suspension was mixed with an equal volume of $0.4 \%$ trypan blue staining solution (Invitrogen, Carlsbad, USA) and transferred onto Countess chamber slides (Invitrogen, Carlsbad, USA) to count the cells in the Countess cell counter (Invitrogen, Carlsbad, USA).

Citric-crystal violet staining was performed to count cell nuclei on carriers to determine multiplicity of infection (MOI). Here, $1 \mathrm{ml}$ of evenly suspended culture with carriers was removed and allowed to settle for $15 \mathrm{~min}$. The supernatant was discarded. The carriers with cells were washed with PBS once, then resuspended in $0.1 \mathrm{M}$ citric acid, containing $0.1 \%(\mathrm{w} / \mathrm{v})$ crystal violet and incubated at $37^{\circ} \mathrm{C}$ for $1 \mathrm{~h}$. The mixture was then gently pipetted and the cell number was determined by counting the released nuclei using a Neubauer cell counting chamber.

The glucose concentration was measured with a glucose blood sugar measuring device (STADA, Bad Vilbel, Germany). For this, one drop of cell culture medium was placed on the glucose test strip and measured with the device. The measured glucose value is expressed in $\mathrm{mg} / \mathrm{dl}$. After unit conversion into $\mathrm{mmol} / \mathrm{l}$, the total consumed glucose was calculated.

\section{Virus stock, time of infection, and quantification}

For H-1PV production, a virus stock of wild-type H-1PV was produced via transfection (Kestler et al., 1999) of NB-324 K cells and subsequently propagated by two rounds of infection. The virus was quantified with a plaque formation assay (see Leuchs et al., 2016), for a description of the method). Time of infection (TOI) was either at seeding, based on Countess cell count (simultaneous infection and seeding), or at day 3 (non-simultaneous infection), based on citric acid nuclei count for carrier cultures or Countess cell count for stationary cultures.

\section{Cell cultivation and virus production in stationary culture}

\section{Simultaneous seeding and infection}

$3.6 \mathrm{E} 4$ cells $/ \mathrm{cm}^{2}$ were seeded in T175 flasks with $20 \mathrm{ml}$ of either MEM full or VP-SFM ${ }^{\mathrm{TM}}$ full, VP-SFM ${ }^{\mathrm{TM}}$ w/o FBS, or VP-SFM ${ }^{\mathrm{TM}}$ full Gln (see Supplemental Table S1) and simultaneously infected. Cells were harvested at 4 days postinfection (dpi). 


\section{Non-simultaneous seeding and infection}

$7.9 \mathrm{E} 3$ cells $/ \mathrm{cm}^{2}$ were seeded in T175 flask with $20 \mathrm{ml}$ of either MEM full, VP-SFM ${ }^{\mathrm{TM}}$ full, or VP-SFM ${ }^{\mathrm{TM}}$ cell expansion medium (Supplemental Table S1). After 3 days of cell expansion, the medium was completely exchanged with MEM full for cells that were seeded in MEM or for cells seeded in VP-SFM ${ }^{\mathrm{TM}}$ with VP-SFM ${ }^{\mathrm{TM}}$ w/o FBS or VP-SFM ${ }^{\mathrm{TM}}$ infection medium. Simultaneously, cells were infected with a MOI of 0.01 or 0.05 according to the Countess cell count of a reference T175 flask. On day 5, another $100 \%$ medium exchange with VP-SFM ${ }^{\mathrm{TM}}$ w/o FBS was performed for cells that had been in VP-SFM ${ }^{\mathrm{TM}}$ infection medium since day 3 (Supplemental Fig. S1). Cells were harvested on day 7 .

\section{Carrier preparation}

Microcarrier and macrocarrier (termed "carriers" when both systems are discussed) characterization is shown in Table 1. Microcarriers were handled and stored in bottles that were siliconized with Sigmacote (Sigma-Aldrich, Steinheim am Albuch, Germany) according to the manufacturer's instructions. Non-cationic microcarriers were hydrated and autoclaved in aqua ad. injectable (B. Braun, Melsungen, Germany), cationic microcarriers in $1 \times \mathrm{PBS}$ without $\mathrm{Ca}^{2+}$ and $\mathrm{Mg}^{2+}$, according to the manufacturer's instructions. Macrocarriers were sterile when supplied and hydrated in cell culture medium for $30 \mathrm{~min}$ at $37^{\circ} \mathrm{C}$ before use.
Cell cultivation and production systems for carriers

\section{Screening in 24-well plates}

Screening experiments of the carriers were performed in 24-well, ultra-low attachment plates (Corning, Kennebunk, USA) with $1 \mathrm{ml}$ VP-SFM ${ }^{\mathrm{TM}}$ full per well, at $37{ }^{\circ} \mathrm{C}, 5 \% \mathrm{CO}_{2}$, and $100 \mathrm{rpm}$ orbital agitation with Max Q $2000 \mathrm{CO}_{2}$ Plus (Thermo Fisher Scientific, New York, USA). Stationary controls were treated like carrier samples but seeded in 6-well plates $\left(9.6 \mathrm{~cm}^{2}\right.$ growth area) with $2 \mathrm{ml}$ cell culture medium per well without agitation.

For simultaneous seeding and infection, $10 \mathrm{~cm}^{2}$ or 11.3 $\mathrm{cm}^{2}$ of carrier was added per well to three wells. Macrocarriers from iCELLis ${ }^{\circledR}$ were cut in half to fit into a well. Then, $1 \mathrm{ml} \mathrm{VP-SFM}{ }^{\mathrm{TM}}$ full with NB-324 K cells, corresponding to a seeding density of $4 \mathrm{E} 4$ cells $/ \mathrm{cm}^{2}$, was added to each well and infected with MOI of 0.01. Cells were harvested 4 days postinfection.

For non-simultaneous seeding and infection, $5 \mathrm{~cm}^{2}$ of growth area was added per well in 2 wells. Then, $1 \mathrm{ml} \mathrm{VP-}$ SFM $^{\mathrm{TM}}$ full with NB-324 K cells, corresponding to a seeding density of $2 \mathrm{E} 4$ or $4 \mathrm{E} 4$ cells $/ \mathrm{cm}^{2}$, was added to each well. On day 3 , both wells per carrier were pooled and the nuclei from a sample counted. Cells were infected (MOI of 0.01 ) by adding fresh cell culture medium VP-SFM ${ }^{\mathrm{TM}}$ full, including the virus and fresh carrier, doubling the total growth area from 10 to $20 \mathrm{~cm}^{2}$ and the cell culture volume from 2 to $4 \mathrm{ml}$ for each pool. The pool of spent and fresh carrier was then split into 3 wells with a $5-\mathrm{cm}^{2}$ growth area and $1 \mathrm{ml}$ cell culture medium per well. Cells were harvested 4 days postinfection on day 7.

Table 1 Overview of microcarriers and macrocarriers

\begin{tabular}{|c|c|c|c|c|c|}
\hline Carrier & Brand & Name & Abbreviation & Charge & Structure \\
\hline \multirow{9}{*}{$\begin{array}{l}\text { Microcarrier for suspen- } \\
\text { sion }\end{array}$} & \multirow{4}{*}{$\begin{array}{l}\text { Pall (Hoegaarden, Bel- } \\
\text { gium) }\end{array}$} & SoloHill@ Hillex®II & HII & Cationic (DEAE group) & High-density, solid \\
\hline & & SoloHill@ Star-Plus & SP & Neutral & Solid \\
\hline & & SoloHill@ Plastic & $\mathrm{P}$ & Neutral & Solid \\
\hline & & SoloHill@ Plastic Plus & PP & Cationic (DEAE group) & Solid \\
\hline & \multirow[t]{2}{*}{$\begin{array}{l}\text { Corning (Kennebunk, } \\
\text { USA) }\end{array}$} & $\begin{array}{l}\text { Enhanced attachment } \\
\text { CellBIND }{ }^{\circledR}\end{array}$ & EA & Neutral & Solid \\
\hline & & $\begin{array}{l}\text { Low Concentration Syn- } \\
\text { themax } ® \text { II }\end{array}$ & SII & RGD* modified & Solid \\
\hline & \multirow[t]{3}{*}{ Cytiva (Uppsala, Sweden) } & Cytodex ${ }^{\circledR} 1$ & CD1 & Cationic (DEAE group) & Solid \\
\hline & & Cytopore $^{\mathrm{TM}} 1$ & $\mathrm{CP} 1$ & Cationic (DEAE group) & Porous \\
\hline & & Cytopore $^{\mathrm{TM}} 2$ & $\mathrm{CP} 2$ & Cationic (DEAE group) & Porous \\
\hline \multirow{2}{*}{$\begin{array}{l}\text { Macrocarrier for fixed- } \\
\text { bed }\end{array}$} & Eppendorf (Enfield, USA) & Fibra-Cel® & $\mathrm{FC}$ & Neutral & Macroporous \\
\hline & $\begin{array}{l}\text { Pall (Hoegaarden, Bel- } \\
\text { gium) }\end{array}$ & $\begin{array}{l}\text { Macrocarrier from iCEL- } \\
\text { Lis } ®\end{array}$ & $\mathrm{iC}$ & Neutral & Macroporous \\
\hline
\end{tabular}

*RGD-containing sequence from the human ECM protein vitronectin, KGGPQVTRGDVFTMP, which promotes adhesion in a variety of cells 


\section{Microcarriers in an Erlenmeyer flask}

After screening, enhanced attachment (EA) and Cytodex ${ }^{\circledR}$ 1 (CD1) microcarriers were selected for upscaling experiments in a $125-\mathrm{ml}$ Erlenmeyer flask with $40 \mathrm{ml} \mathrm{VP-SFM}^{\mathrm{TM}}$ full and $10 \mathrm{~cm}^{2} / \mathrm{ml}$ growth area, at $37{ }^{\circ} \mathrm{C}, 5 \% \mathrm{CO}_{2}$, and 60-70 rpm orbital agitation with Max Q $2000 \mathrm{CO}_{2}$ Plus (Thermo Fisher Scientific, New York, USA). Here, 2E4 cells $/ \mathrm{cm}^{2}$ was seeded, and agitation was reduced to $0 \mathrm{rpm}$ for $30 \mathrm{~min}$ or to $30 \mathrm{rpm}$ for $3 \mathrm{~h}$ to promote cell attachment. On day 3 , a sample was taken to determine cell density with nuclei count for virus infection (MOI of 0.01), and the virus was added during a 50\% medium exchange on the same day with fresh VP-SFM ${ }^{\mathrm{TM}}$ full.

\section{Virus production in Erlenmeyer flasks with macrocarriers}

Fibra-Cel ${ }^{\circledR}$ and macrocarrier from iCELLis ${ }^{\circledR}$ were also tested in 125-ml Erlenmeyer flasks with parameters similar to those described for the microcarriers. However, orbital agitation was 30-100 rpm, and agitation during seeding was either $100 \mathrm{rpm}$ or a cycle of $40 \mathrm{rpm}$ for $1 \mathrm{~min}$ and then $0 \mathrm{rpm}$ for $30 \mathrm{~min}$, which was repeated four times to a total seeding time of $2 \mathrm{~h}$.

\section{Virus production in Spinner flasks with carriers}

EA and CD1 microcarriers were further scaled up in a 250$\mathrm{ml}$ Spinner flask (Integra Biosciences, Switzerland) and Fibra-Cel ${ }^{\circledR}$ and macrocarrier from iCELLis ${ }^{\circledR}$ in a $500-\mathrm{ml}$ Spinner flask (Integra Biosciences, Biebertal, Germany) with $100 \mathrm{ml}$ VP-SFM ${ }^{\mathrm{TM}}$ full and $10 \mathrm{~cm}^{2} / \mathrm{ml}$ growth area, at $37{ }^{\circ} \mathrm{C}, 5 \% \mathrm{CO}_{2}$, and $15-30 \mathrm{rpm}$ agitation. Then, 2E4 cells/ $\mathrm{cm}^{2}$ was seeded, and agitation was reduced to $0 \mathrm{rpm}$ for $30 \mathrm{~min}$ or a cycle of $40 \mathrm{rpm}$ for $1 \mathrm{~min}$ and then $0 \mathrm{rpm}$ for $30 \mathrm{~min}$, which was repeated four times to a total seeding time of $2 \mathrm{~h}$. On day 3 , a sample was taken to determine cell density with nuclei count for virus infection (MOI of 0.01 or 0.05 ), and the virus was added during a $50 \%$ medium exchange with VP-SFM ${ }^{\mathrm{TM}}$ full on the same day. Cells were harvested 4 days postinfection on day 7 .

\section{Virus production in iCELLis ${ }^{\circledR}$ nano bioreactor}

The iCELLis ${ }^{\circledR}$ nano bioreactor system (Pall, Port Washington, USA) was tested in $0.53-\mathrm{m}^{2}$ and $4-\mathrm{m}^{2}$ fixed-bed sizes (Pall, Port Washington, USA). After preparing the fixed-bed according to the manufacturer's instructions, bioreactors were filled with $850 \mathrm{ml}$ VP-SFM ${ }^{\mathrm{TM}}$ cell expansion medium $\left(0.16 \mathrm{ml} / \mathrm{cm}^{2}\right)$. For the $4-\mathrm{m}^{2}$ fixed bed, a recirculation loop (Pall, Port Washington, USA) supplying an additional $3150 \mathrm{ml}$ VP-SFM ${ }^{\mathrm{TM}}$ cell expansion medium was connected $\left(0.10 \mathrm{ml} / \mathrm{cm}^{2}\right)$. Then, $5 \mathrm{E} 3 \mathrm{cells} / \mathrm{cm}^{2}$ was seeded for the $0.53-\mathrm{m}^{2}$ fixed-bed or $9 \mathrm{E} 3$ cells $/ \mathrm{cm}^{2}$ for the $4-\mathrm{m}^{2}$ fixed-bed and maintained at $37{ }^{\circ} \mathrm{C}, \mathrm{pH} 7.3$, above $30-40 \%$ dissolved oxygen. After 3 days of cell expansion, several macrocarriers were taken from the top of the fixed bed and cells were counted, followed by infection with an MOI of 0.01 during a $100 \%$ medium exchange to VP-SFM ${ }^{\mathrm{TM}}$ infection medium. Two days postinfection, an additional 100\% medium exchange to VP-SFM ${ }^{\mathrm{TM}}$ w/o FBS medium was performed. Cells were harvested 4 days postinfection on day 7 .

\section{Harvest}

For carrier cultures in wells, or Erlenmeyer or Spinner flasks, the cell culture medium was removed 4 days postinfection, and then carriers were treated for $30 \mathrm{~min}$ at $37{ }^{\circ} \mathrm{C}$ with $0.02 \mathrm{ml} / \mathrm{cm}^{2} 1 \%$ Triton ${ }^{\circledR}$ X-100 (Sigma-Aldrich, St. Louis, USA), 0.1 M Tris-HCl, pH 9.5, for cell lysis.

For iCELLis ${ }^{\circledR}$ nano-cultures, the cell culture medium was removed 4 days postinfection. Then, the cells in the fixed bed were rinsed with PBS and lysed with $0.094 \mathrm{ml} / \mathrm{cm}^{2}$ $\left(0.53 \mathrm{~m}^{2}\right)$ or $0.014 \mathrm{ml} / \mathrm{cm}^{2}\left(4 \mathrm{~m}^{2}\right)$ detergent-based buffer.

For stationary cultures, cell lysis via a freeze/thaw process was performed. The medium was removed, and infected cells were washed with $1 \times$ PBS. The medium supernatant and detached cells were centrifuged for $5 \mathrm{~min}$ at $5000 \times g$. The pellet was washed with PBS, resuspended with $0.02 \mathrm{ml} /$ $\mathrm{cm}^{2} 0.05 \mathrm{M}$ Tris-HCl, $\mathrm{pH} 8.7$ (VT), for $30 \mathrm{~min}$ at $37^{\circ} \mathrm{C}$, and subjected to three freeze (liquid nitrogen) and thaw $\left(37^{\circ} \mathrm{C}\right)$ cycles. In addition, the following steps were taken during medium optimization and FBS reduction: After centrifugation for $5 \mathrm{~min}$ at $5000 \times \mathrm{g}$, cell debris was discarded. The cell lysate was then sonicated at $48 \mathrm{~W}$ for $1 \mathrm{~min}$ with a Sonorex Super $10 \mathrm{P}$ ultrasonic homogenizer (Bandelin, Berlin, Germany) and treated with DNAse (50 U/ml, Sigma-Aldrich, Steinheim am Albuch, Germany) after adding $5 \mathrm{mM} \mathrm{MgCl} 2$ for $30 \mathrm{~min}$ at $37^{\circ} \mathrm{C}$ to eliminate non-encapsidated viral DNA and contaminating host cell DNA.

\section{Results}

To increase the yield, while lowering production costs and avoiding undesired products of animal origin, VP-SFM ${ }^{\mathrm{TM}}$ cell culture medium was tested and compared with a previously described MEM medium (Leuchs et al., 2016), employing simultaneous or non-simultaneous infection and seeding. With simultaneous seeding and infection, omitting FBS from MEM decreased the virus yield from 8.3E6 plaque-forming units (PFU) $/ \mathrm{cm}^{2}$ to $1.7 \mathrm{E} 4 \mathrm{PFU} / \mathrm{cm}^{2}$ (Fig. 1a). VP-SFM ${ }^{\mathrm{TM}}$ supplemented with 5\% FBS or $0 \%$ FBS achieved an increased virus yield compared to MEM, at 2.7E7 PFU/ $\mathrm{cm}^{2}$ and $1.8 \mathrm{E} 7 \mathrm{PFU} / \mathrm{cm}^{2}$, respectively. Glutamine was fully consumed in MEM by the end of the 
Fig. 1 a Effect of FBS removal on H-1PV-specific virus yield with MEM (hatching lines) or VP-SFM ${ }^{\mathrm{TM}}$ (black) cell culture media. Here, 2.6E4 NB-324 K cells $/ \mathrm{cm}^{2}$ was simultaneously seeded and infected with a MOI of 0.05 . Cells were harvested and lysed 4 days postinfection with a freeze-thaw process in lysis buffer. b Similar H-1PVspecific virus yield with 5\% FBS or two-step FBS reduction scheme. Here, 3.6E4 NB-324 K cells $/ \mathrm{cm}^{2}$ was seeded in VP-SFM ${ }^{\mathrm{TM}}$ medium supplemented with $5 \%$ or $2 \%$ FBS. After 3 days of cell expansion, the infection with a MOI of 0.05 and a $100 \%$ medium exchange with $5 \%$ or $0 \%$ FBS was performed. Cells were harvested and lysed 4 days postinfection with a freeze-thaw process in lysis buffer. c Boost of $\mathrm{H}-1 \mathrm{PV}$-specific virus yield with three-step FBS reduction using VPSFM $^{\mathrm{TM}}$. Here, $5 \mathrm{E} 3 \mathrm{NB}-324 \mathrm{~K}$ cells $/ \mathrm{cm}^{2}$ was seeded with $2 \% \mathrm{FBS}$. After 3 days of cell expansion, the first $100 \%$ medium exchange to either $1 \%$ or $0 \%$ FBS and infection with a MOI of 0.01 was performed for production phase I from day 3 to day 5 . Two days postinfection, a second $100 \%$ medium exchange was performed without FBS for production phase II: day 5-day 7. Cells were harvested and lysed 4 days postinfection on day 7

process (data not shown). Therefore, higher glutamine ( $6 \mathrm{mM}$ for VP-SFM ${ }^{\mathrm{TM}}$ and $5 \mathrm{mM}$ for MEM) concentrations were supplemented with 5\% FBS for both cell culture media. These conditions only increased the virus yield for MEM from 1.8E6 to 5.6E6 PFU/cm². Nevertheless, VP$\mathrm{SFM}^{\mathrm{TM}}$ demonstrated an overall better yield of 1.6E7 PFU/ $\mathrm{cm}^{2}$ (Fig. 2). Comparing the two cell culture media suggests that $4 \mathrm{mM}$ glutamine supplementation is sufficient for VP$\mathrm{SFM}^{\mathrm{TM}}$ and results in higher yields even at lower amounts of FBS than for MEM. Thus, MEM was replaced with VP$\mathrm{SFM}^{\mathrm{TM}}$ for further optimizing the process.

Afterward, we compared a two-step with a three-step FBS reduction strategy using $100 \%$ medium exchanges. See Fig. $\mathrm{S} 1$ for an overview of all medium exchange strategies with VP-SFM ${ }^{\mathrm{TM}}$ medium. All strategies started with 5\% FBS in the seed train, followed by 3 days of cell expansion in 5\% or $2 \%$ FBS and a $100 \%$ medium exchange with simultaneous infection on day 3 after seeding. In the two-step process, when infection is done with 0\% FBS (2-0\%) the resulting virus yield of $1.0 \mathrm{E} 7 \mathrm{PFU} / \mathrm{cm}^{2}$ was similar to that for $5 \% \mathrm{FBS}$ supplementation (5-5\%) over the whole process (Fig. 1b). In the three-step strategies, the $100 \%$ medium exchange on day 3 after seeding with $2 \%$ FBS was supplemented with either $1 \%$ FBS (2-1-0\%) or without FBS (2-0-0\%), followed by a second $100 \%$ medium exchange without FBS on day 5 for both. With three independent experiments, we demonstrated that the 2-1-0\% FBS strategy resulted in twice the yield of the 2-0-0\% FBS strategy up to $7.7 E 7 \mathrm{PFU} / \mathrm{cm}^{2}$ (Fig. 1c). In summary, the results indicate that depletion of FBS over the process is feasible with the highest virus yield achieved by applying the 2-1-0\% FBS strategy. However, FBS includes components needed for a high virus yield which cannot be supplied by VP-SFM ${ }^{\mathrm{TM}}$ alone.
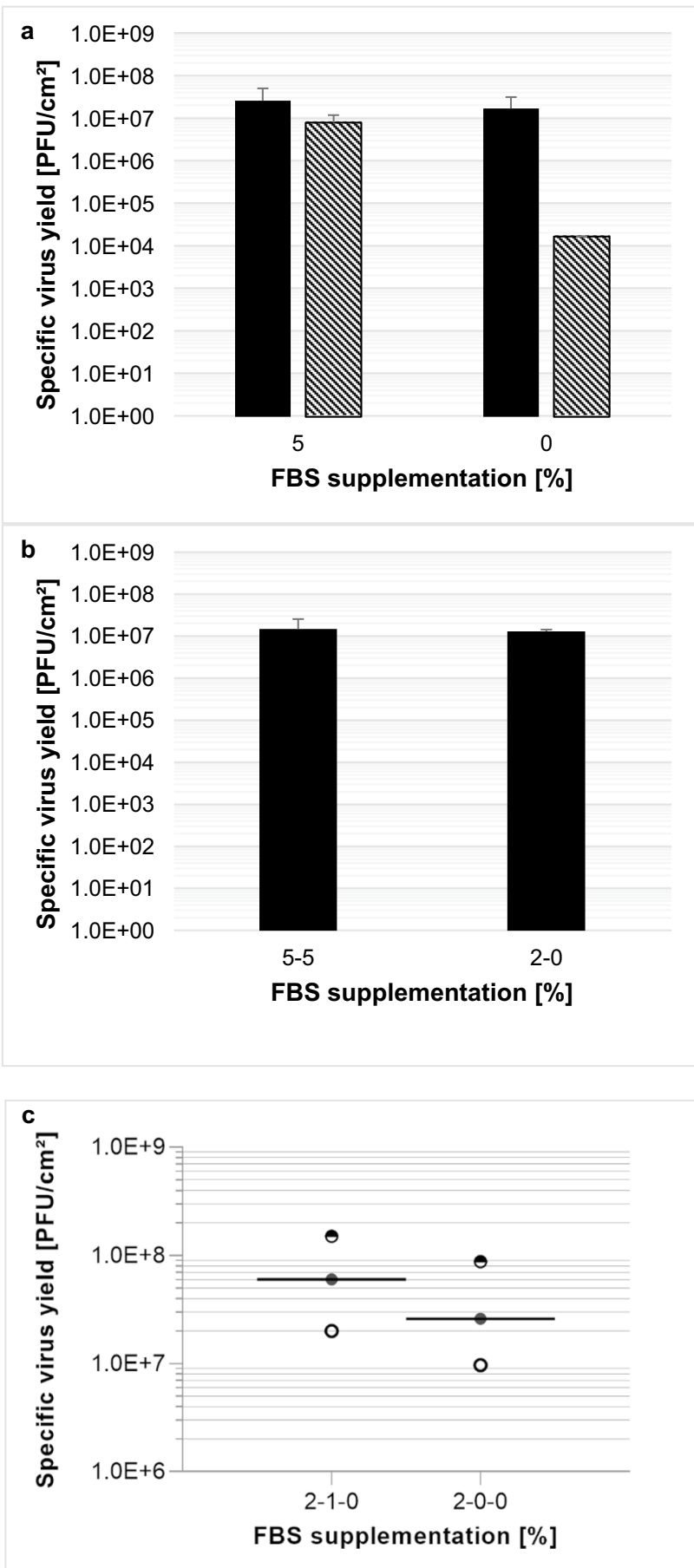

\section{Chemical cell lysis needed for large-scale H-1PV harvest}

In our process, the majority of infective virus particles are cell-associated at the time of harvest. To harvest H-1PV, a freeze-thaw cell lysis in Tris-EDTA buffer (VTE) (Leuchs et al., 2016) or Tris-HCl buffer (VT) (Leuchs et al., 2017) was previously reported for stationary cultures. For large-scale production with adherent 


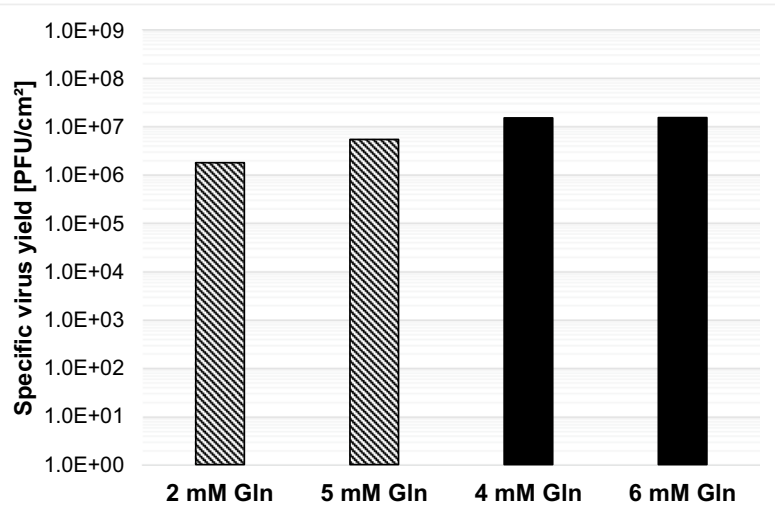

Fig. 2 Effect of glutamine supplementation on H-1PV-specific virus yield MEM (hatching lines) or VP-SFM ${ }^{\mathrm{TM}}$ (black) medium. Here, 3.6E4 NB-324 K cells $/ \mathrm{cm}^{2}$ were simultaneously seeded and infected with a MOI of 0.05 in 5\% FBS. Cells were harvested and lysed 4 days postinfection

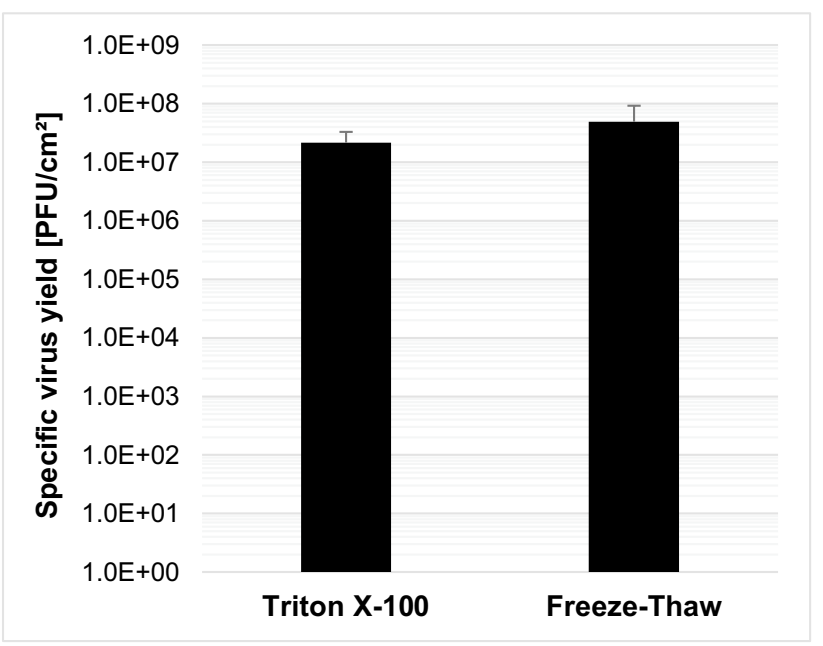

Fig. 3 Comparison of harvest with Triton ${ }^{\circledR}$ X-100 process or the freeze-thaw process in VT buffer for cell lysis. NB-324 K cells were seeded in VP-SFM ${ }^{\mathrm{TM}}$ with $4 \mathrm{E} 4$ cells $/ \mathrm{cm}^{2}$ in stationary 6-well plates and simultaneously infected with a MOI of 0.01 . Cells were harvested and lysed 4 days postinfection

cells on carriers, a scalable cell lysis is required. Therefore, we developed an alternative cell lysis method with Triton ${ }^{\circledR} \mathrm{X}-100$, resulting in a satisfactory virus yield $>2.0 \mathrm{E} 7 \mathrm{PFU} / \mathrm{cm}^{2}$ (Fig. 3).

Taken together, medium optimization and the three-step medium exchange strategy with Triton ${ }^{\circledR} \mathrm{X}-100$ lysis constitute a solid basis for upscaling production.

\section{Screening of cell growth on microcarriers and macrocarriers in a 24-well scale}

For large-scale production with adherent cells, microcarriers can be employed for suspension culture or macrocarriers for a fixed-bed bioreactor. We screened cell growth, bead-to-bead-transfer capability, and virus yield for eleven carrier types. Direct cell counting on carriers was difficult. Therefore, we measured glucose consumption as an indicator of growth.

Figure 4a shows the glucose consumption of cells cultivated on different carriers (without macrocarrier from iCELLis() for up to 6 days with a surface-to-medium volume ratio of $5 \mathrm{~cm}^{2} / \mathrm{ml}$ and a seeding density of $2 \mathrm{E} 4 \mathrm{cells} / \mathrm{cm}^{2}$. All microcarriers show a glucose consumption of 6 to $8 \mu \mathrm{mol} /$ well within 4 days and 15 to $22 \mu \mathrm{mol} /$ well after 3 additional days, except for $\mathrm{CP} 1$ and $\mathrm{FC}$, which consumed less glucose. In comparison, with doubled seeding cell density of 4E4 cells $/ \mathrm{cm}^{2}$ and $5 \mathrm{~cm}^{2} / \mathrm{ml}$ medium, glucose consumption was similar to 2E4 seeded cells $/ \mathrm{cm}^{2}$, while $10 \mathrm{~cm}^{2} / \mathrm{ml}$ showed a 1.5-fold higher glucose consumption within 4 days, except for macrocarrier FC (Fig. 4b). Overall, cell growth was satisfactory at $5 \mathrm{~cm}^{2} / \mathrm{ml}$ and $10 \mathrm{~cm}^{2} / \mathrm{ml}$ for all carriers, with the exception of the porous microcarriers $\mathrm{CP} 1$ and $\mathrm{CP} 2$.

\section{Microcarriers are capable of bead-to-bead cell transfer}

Some cell lines are capable of building individual cell bridges from a confluent microcarrier to a fresh one for continued cell growth. This bead-to-bead transfer without trypsination can facilitate seed train cell expansion because fresh microcarriers only need to be added. To test bead-tobead transfer capability, cells were seeded on microcarriers, and more microcarriers were added with the fresh cell culture medium by a 1:2 split on day 4 and day 7 . Trypan blue cell count of microcarriers after trypsination was performed on day 4 before the 1:2 split and on day 10. According to trypan blue cell count after trypsination, only the non-porous microcarriers were capable of bead-to-bead transfer, as observed by the increase in cells from day 4 to day 10 of up to $5 \mathrm{E} 5$ cells $/ \mathrm{cm}^{2}$ (Fig. 5). In Fig. 6, the bead-to-bead transfer with cell bridges is shown with microcarrier EA and CD1. The capability of bead-to-bead transfer without trypsination suggests good cell expansion capability in scaled-up seed trains for all nonporous microcarriers with NB-324 K cells. This result confirms our findings of a lack of cell growth on porous microcarriers $\mathrm{CP} 1$ and $\mathrm{CP} 2$. 
Fig. 4 Glucose consumption of NB-324 K cells on different carriers for cell growth screening, shaken at $100 \mathrm{rpm}$ in 24-well plates. a Glucose consumption from day 0 to day 4 and day 4 to day 6 with $5 \mathrm{~cm}^{2} / \mathrm{ml}$ and $2 \mathrm{E} 4$ seeded cells $/ \mathrm{cm}^{2}$. b Glucose consumption with 4E4 seeded cells $/ \mathrm{cm}^{2}$ either $5 \mathrm{~cm}^{2} / \mathrm{ml}$ or 10 $\mathrm{cm}^{2} / \mathrm{ml}$ from day 0 to day 4
Fig. 5 Increase in cell density with bead-to-bead transfer on microcarriers on days 4 and 7. Here, 4E4 NB-324 K cells/ $\mathrm{cm}^{2}$ and $5 \mathrm{~cm}^{2} / \mathrm{ml}$ were seeded in 24-well plates and shaken at $100 \mathrm{rpm}$. On days 4 and 7, 50\% of medium with microcarriers were taken out and filled up with fresh medium with microcarriers for a constant ratio of microcarriers to medium volume. No increase in cell density of $\mathrm{CP} 1$ on day 4 and for $\mathrm{CP} 2$ on day 10 was observed
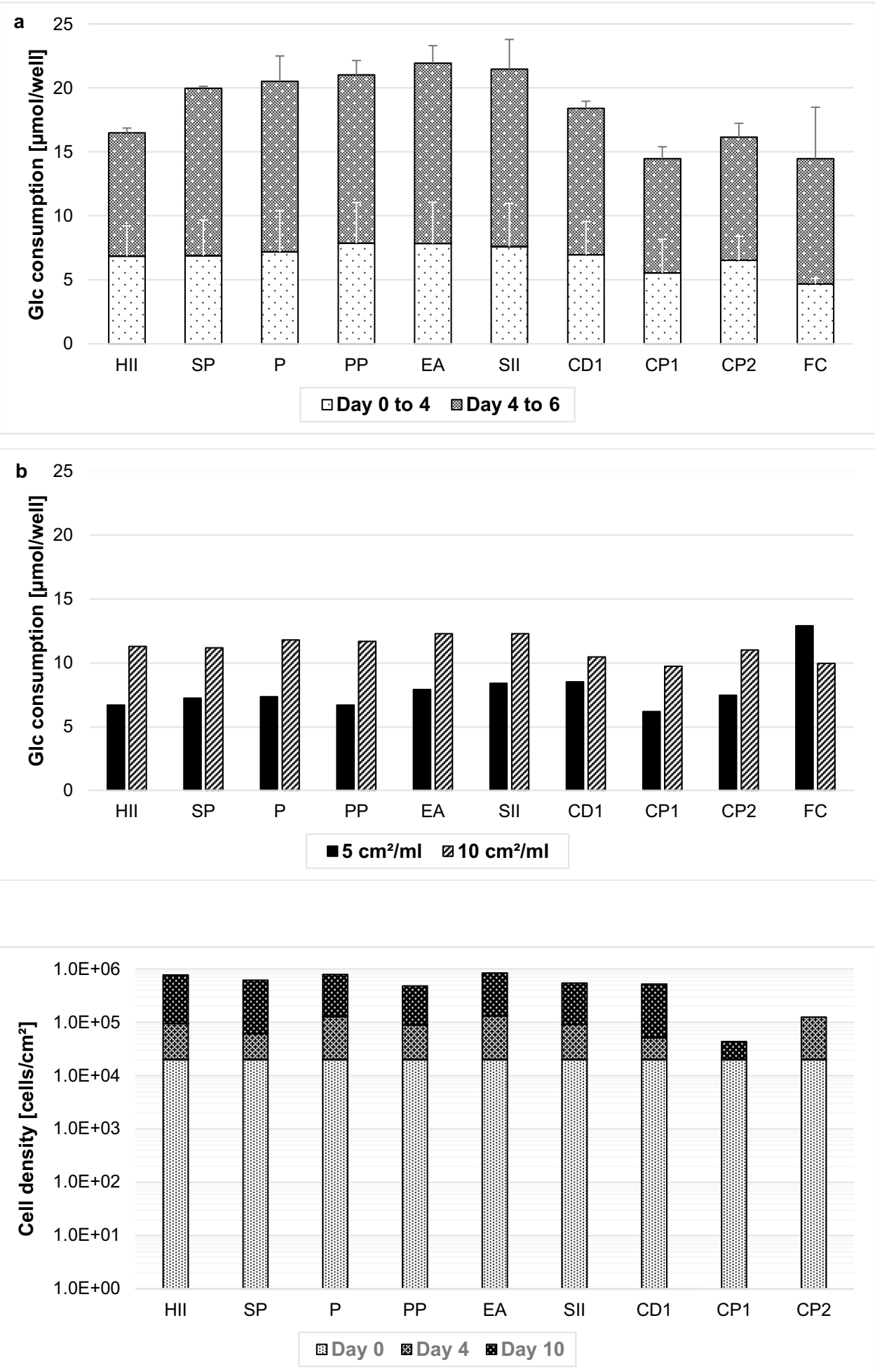

\section{Cytodex ${ }^{\circledast} 1$ and macrocarrier from iCELLis ${ }^{\circledR}$ show the highest $\mathrm{H}-1 \mathrm{PV}$ yield}

After characterizing cell growth on the carriers, we applied different production strategies (simultaneous infection/ non-simultaneous seeding and infection, with or without bead-to-bead transfer) to identify conditions most suited for high virus production of $\mathrm{H}-1 \mathrm{PV}$.

Simultaneous infection and seeding of carriers in 24-well, ultra-low attachment plates resulted in similar virus yield for most microcarriers (HII, SP, P, PP, EA, SII, CP1, CP2). The highest yield was achieved with microcarrier CD1 and 

of cell bridges between confluriers. a Enhanced attachment $(\times 10)$; b Cytodex ${ }^{\circledR} 1(\times 10)$; scale bar $=200 \mu \mathrm{m}$
Fig. 6 Microscopic observation ent and freshly added microcar-
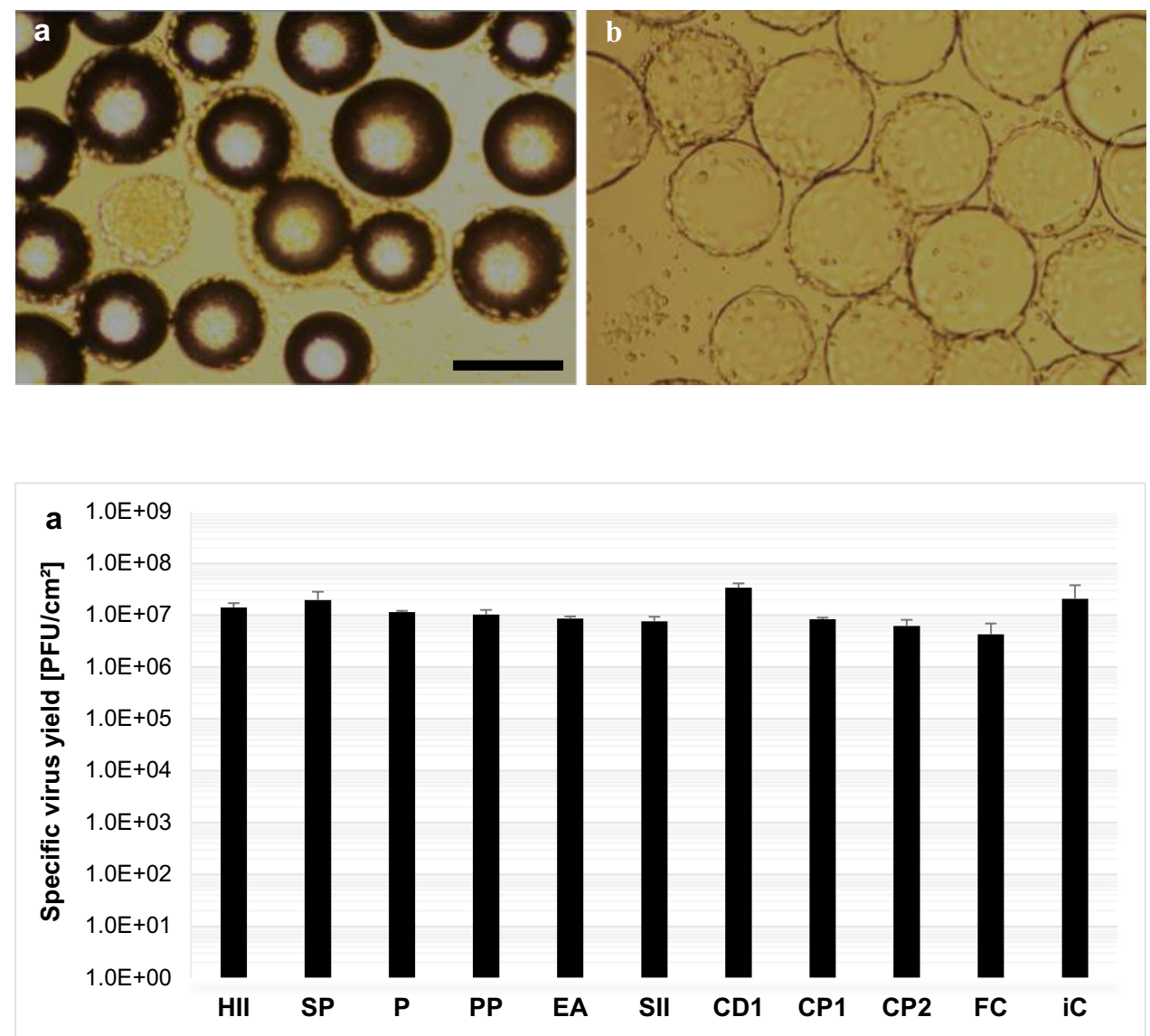

Fig. 7 a H-1PV-specific virus yield screening with different carriers. Here, 4E4 NB-324 K cells $/ \mathrm{cm}^{2}$ was seeded with 10 $\mathrm{cm}^{2} / \mathrm{ml}\left(11.2 \mathrm{~cm}^{2} / \mathrm{ml}\right.$ for iC) growth area of each carrier in 24-well plates and shaken at $100 \mathrm{rpm}$. Cells were harvested and lysed 4 days postinfection. b H-1PV-specific virus yield with different microcarriers after bead-to-bead transfer. 2E4 (black) or 4E4 (hatching lines) NB-324 K cells $/ \mathrm{cm}^{2}$ was seeded with $5 \mathrm{~cm}^{2} / \mathrm{ml}$ growth area of each microcarrier in 24-well plates and orbitally shaken at $100 \mathrm{rpm}$. After 3 days of cell expansion, cells were infected with a MOI of 0.01 , while growth surface and medium volume were doubled by addition of fresh microcarriers in fresh medium, followed by a $1: 2$ split to return to start conditions of medium volume and microcarrier density. Cells were harvested and lysed 4 days postinfection

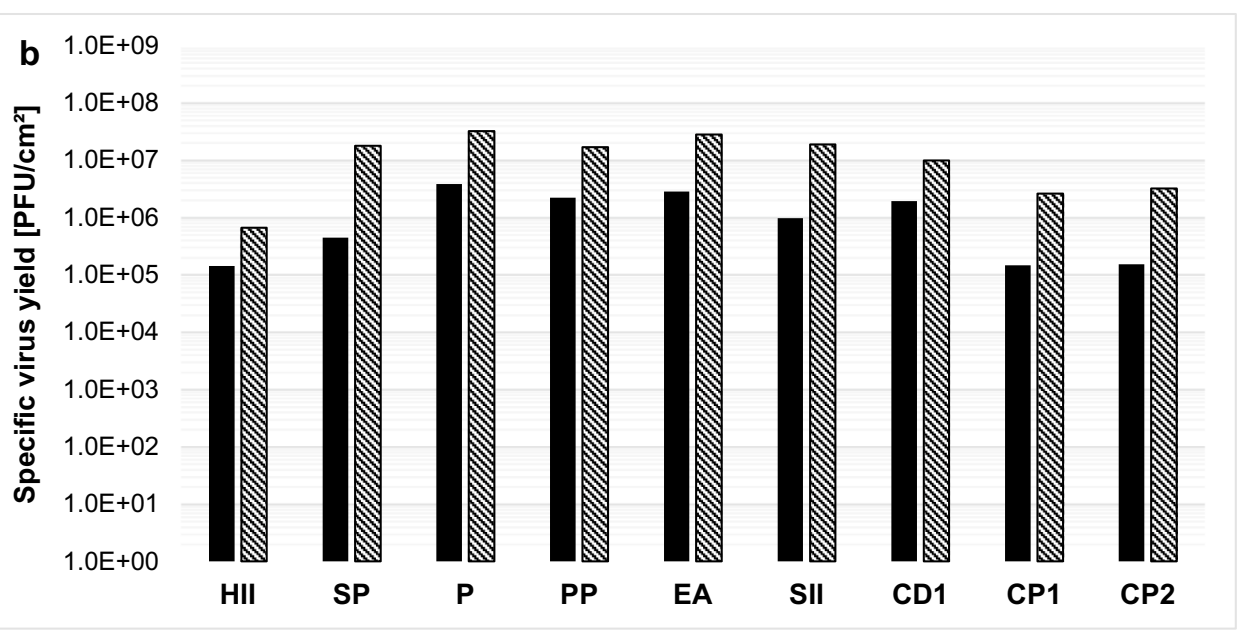

macrocarrier iC, 3.4E7 PFU/ $/ \mathrm{cm}^{2}$, and 2.0E7 PFU/ $\mathrm{cm}^{2}$, respectively (Fig. 7a). Macrocarrier FC had the lowest yield of $4.2 \mathrm{E} 6 \mathrm{PFU} / \mathrm{cm}^{2}$.

For non-simultaneous seeding and infection, in addition to the $4 \mathrm{E} 4$ cells $/ \mathrm{cm}^{2}$ density, a $50 \%$ reduced seeding density of $2 \mathrm{E} 4$ cells $/ \mathrm{cm}^{2}$ was tested for higher yield. Three days after seeding, the cells were infected and a 1:2 split, adding fresh cell culture medium and microcarriers to maintain volume and microcarrier density, was performed for bead-to-bead transfer. Virus yield was highest at a seeding density of 4E4 cells $/ \mathrm{cm}^{2}$, which was similar for most microcarriers compared to simultaneous seeding and infection without beadto-bead transfer, with the exception of the solid HII and the porous $\mathrm{CP} 1$ and $\mathrm{CP} 2$ carriers (Fig. $7 \mathrm{~b}$ ). Taken together, high virus production seems possible with all tested strategies but requires a seeding density of $4 \mathrm{E} 4$ cells $/ \mathrm{cm}^{2}$. In addition, HII and porous microcarriers CP1 and CP2 only showed a high yield for simultaneous infection and seeding without bead-to-bead transfer. 
Upscaling from 24-well plate format up to $100 \mathrm{ml}$ with Erlenmeyer and Spinner flasks was examined with two selected microcarriers and two macrocarriers. The microcarrier CD1 showed the highest yield, while microcarrier EA surface is comparable to that for 10-layer CellSTACK ${ }^{\circledR}$ chambers. Both macrocarriers for fixed-bed bioreactors were also chosen for upscaling experiments, due to possible limitations associated with 24-well plate, small-scale testing. A wide range of parameters such as seeding and process agitation, carrier densities, cell-seeding densities, MOI, TOI, with/without bead-to-bead transfer, cell culture volume per vessel, and a medium exchange regimen were
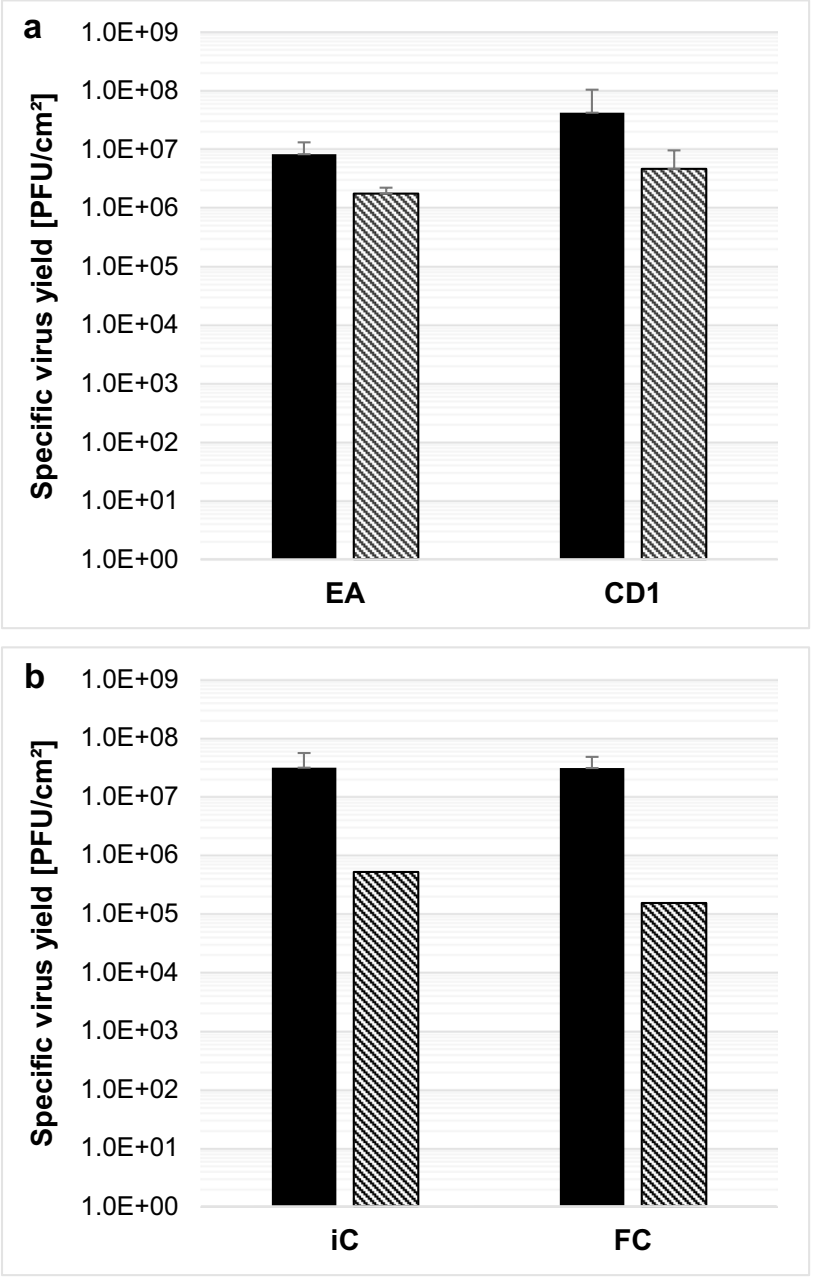

Fig. 8 H-1PV-specific virus yield after scale-up of best-performing microcarriers and macrocarriers. Here, $2 \mathrm{E} 4 \mathrm{NB}-324 \mathrm{~K}$ cells $/ \mathrm{cm}^{2}$ was seeded with $10 \mathrm{~cm}^{2} / \mathrm{ml}$ growth area (a microcarrier EA or CD1; b macrocarrier iC or FC) in a VP-SFM ${ }^{\mathrm{TM}}$ volume of $40 \mathrm{ml}$ per $125-\mathrm{ml}$ Erlenmeyer flask (black) or $100 \mathrm{ml}$ per Spinner flask (hatching lines). For seeding, a cycle of $1 \mathrm{~min}$ at $40 \mathrm{rpm}$, followed by $30 \mathrm{~min}$ at $0 \mathrm{rpm}$, was repeated four times to a total seeding time of $2 \mathrm{~h}$. Then, agitation was set between 30 and $100 \mathrm{rpm}$ for the Erlenmeyer flask or $40 \mathrm{rpm}$ for the Spinner flask. After 3 days of cell expansion, cells were infected with a MOI of 0.01 and $50 \%$ of the medium exchanged with fresh medium. Cells were harvested and lysed 4 days postinfection tested (Supplemental Tables S2 and S3). However, only the most promising parameters with $40 \mathrm{ml}$ cell culture medium in an Erlenmeyer flask and $100 \mathrm{ml}$ in a Spinner flask are shown (Fig. 8a and b).

The microcarrier CD1 reached a yield level of 4.3E7 $\mathrm{PFU} / \mathrm{cm}^{2}$ in the Erlenmeyer flask, but it was $1 \log$ less when upscaled in the Spinner flask. The microcarrier EA had a lower virus yield than $\mathrm{CD} 1$ in all systems.

A 3.0E7 PFU $/ \mathrm{cm}^{2}$ virus yield was achieved with macrocarrier iC and FC in the Erlenmeyer flask, a macrocarrier density of $10 \mathrm{~cm}^{2} / \mathrm{ml}$, and a total cell surface of $400 \mathrm{~cm}^{2}$. However, when upscaled to the Spinner flask, yield was below $1.0 \mathrm{E} 6 \mathrm{PFU} / \mathrm{cm}^{2}$ with $10 \mathrm{~cm}^{2} / \mathrm{ml}$ and $1000-\mathrm{cm}^{2}$ cell surface. The results of $\mathrm{CD} 1$ and both macrocarriers in the Erlenmeyer flask confirm that high virus yield is possible in suspension, and these carriers are the best candidates for further upscaling.

\section{First production in iCELLis ${ }^{\circledast}$ nano bioreactor}

Assuming a yield of $3.0 \mathrm{E} 7 \mathrm{PFU} / \mathrm{cm}^{2}$ that was generated in the Erlenmeyer flask, with the iCELLis ${ }^{\circledR} 500-\mathrm{m}^{2}$ fixedbed, a batch yield of 1.5E14 PFU can be expected (corresponding to 15,000 doses, each with 1E10 PFU). Therefore, virus production was tested in the downscaled iCELLis ${ }^{\circledR}$ nano system.

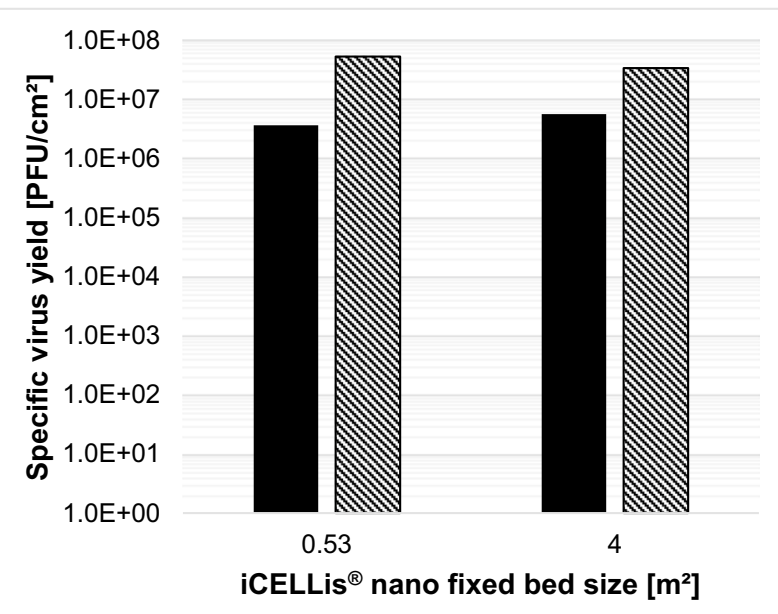

Fig. $9 \mathrm{H}-1 \mathrm{PV}$-specific virus yield in iCELLis ${ }^{\circledR}$ nano with different fixed-bed and respective Tflask run controls. In separate bioreactor runs, $5 \mathrm{E} 3 \mathrm{cells} / \mathrm{cm}^{2}\left(0.53 \mathrm{~m}^{2}\right)$ or $9 \mathrm{E} 3$ cells $/ \mathrm{cm}^{2}\left(4 \mathrm{~m}^{2}\right)$ was seeded in iCELLis ${ }^{\circledR}$ nano fixed-bed (black) and Tflask run control (hatching lines). After 3 days of cell expansion with VP-SFM ${ }^{\mathrm{TM}}$ Cell expansion medium, the first $100 \%$ medium exchange to VP-SFM ${ }^{\mathrm{TM}}$ Infection medium and infection with a MOI of 0.01 was performed for production phase I from day 3 to day 5. Two days postinfection, a second $100 \%$ medium exchange was performed with VP-SFM ${ }^{\mathrm{TM}}$ w/o FBS medium for the production phase II: day 5-day 7. Cells were harvested and lysed 4 days postinfection on day 7 
For production in iCELLis ${ }^{\circledR}$ nano bioreactor, the newly developed medium exchange strategy 2-1-0\% FBS was used. Here, $0.53-\mathrm{m}^{2}$ and $4-\mathrm{m}^{2}$ fixed-bed sizes were tested and resulted in 3.7E6 PFU/ $\mathrm{cm}^{2}$ and $5.7 \mathrm{E} 6 \mathrm{PFU} / \mathrm{cm}^{2}$, respectively (Fig. 9). Both fixed-beds had a comparable but approximately one log step lower yield than did the macrocarrier from iCELLis ${ }^{\circledR}$ in the Erlenmeyer flask and stationary run control.

\section{Discussion}

Patient treatment with the oncolytic parvovirus H-1PV has shown promising results in clinical trials against several types of cancers (Geletneky et al., 2017; Hajda et al., 2021). In preparation for market release, we sought to optimize the culture medium and production process at laboratory scale.

The presented data show the first results for producing $\mathrm{H}-1 \mathrm{PV}$ in a large-scale bioreactor system. However, the process needs to be adapted and optimized according to system parameters such as agitation speed, aeration, seeding cell density, time of infection, multiplicity of infection, and time of harvest.

FBS in cell culture is still common, but problematic in terms of quality, lot-to-lot reproducibility, animal welfare, supply, cost (van der Valk et al., 2018), and potential regulatory restrictions in the future. Therefore, the optimized culture medium VP-SFM ${ }^{\mathrm{TM}}$, suitable for FBS-free production (Liu et al., 2017; Rourou et al., 2007; Martinez et al., 2020) and a two-step medium exchange strategy, was adapted to reduce the required amount of FBS by up to $80 \%$ for a FBSfree harvest at a comparable virus yield. With an additional medium exchange at $2 \mathrm{dpi}$ and three-step FBS reduction from 2 to $1 \%$ and to $0 \%$, a production yield boost of approximately $0.3 \log$ was achieved, while still reducing the FBS needed by up to $40 \%$. By applying this strategy, a high virus production yield with a FBS-free harvest and fewer impurities for the downstream process can be achieved.

In the non-simultaneous seeding and infection process, we could reduce the seeding density from $7.9 \mathrm{E} 3$ cells $/ \mathrm{cm}^{2}$ with MEM-HEPES to $5.0 \mathrm{E} 3 \mathrm{cells} / \mathrm{cm}^{2}$ and maintain a similar virus yield after adapting to VP-SFM ${ }^{\mathrm{TM}}$. In this way, the cell expansion time could be reduced, and fewer resources were needed for the seed train.

For H-1PV harvest, PBS/EDTA cell detachment and cell lysis in Tris-HCl buffer with successive freeze-thaw cycles have been employed in the past. For production screening on different microcarriers and macrocarriers, a Triton ${ }^{\circledR}$ $\mathrm{X}$-100-based chemical cell lysis was introduced due to the limitations of freeze-thaw lysis for upscaling. With Triton ${ }^{\circledR}$ $\mathrm{X}-100$ lysis, satisfactory production yields were achieved on different microcarriers and macrocarriers. Currently, the detergent Triton ${ }^{\circledR} \mathrm{X}-100$ is considered eco-toxic by regulatory authorities (https://echa.europa.eu/authorisation-list).
An alternative, eco-friendlier, and scalable harvest method needs to be developed for future non-experimental applications with a similar or higher efficiency. Tween ${ }^{\circledR} 20$ (Moleirinho et al., 2018) could be considered an alternative detergent.

To simplify the upscaling process with the anchoragedependent production cell line, several microcarriers and macrocarriers were tested. After screening in 24-well plates for growth and virus production properties and selected upscaling into Erlenmeyer and Spinner flasks, the solid microcarrier Cytodex ${ }^{\circledR} 1$ was found to be most suited. Low yield in the Spinner flask was observed with all tested microcarriers and macrocarriers. This was most likely due to device limitations related to propeller shape and speed, resulting in shear stress at the lowest rpm. Indeed, high virus yield has already been reported with Cytodex ${ }^{\circledR} 1$ for adenoviruses and retroviruses (Wu et al., 2002), vaccinia virus (Liu et al., 2017), and influenza virus A (Tree et al., 2001).

With the exception of porous Cytopore ${ }^{\mathrm{TM}} 1$ and Cytopore $^{\mathrm{TM}} 2$, all other microcarriers showed promising beadto-bead cell transfer capability during cell growth and virus production, without the need for a trypsination step. If such a regimen can be exploited in larger-scale systems, it could simplify seed train expansion and production scale-up. Furthermore, the porous surface of Cytopore ${ }^{\mathrm{TM}} 1$ and Cytopore $^{\mathrm{TM}} 2$ might reduce the efficacy of cell migration. Additionally, the porous microcarriers showed lower cell growth as indicated by cell count, lower glucose consumption rate, and reduced production yield. Wu et al. (2002) published similar results with human kidney 293 cells. However, in our experiments, the surface pores may have impeded cell detachment after trypsination for cell counting and virus detachment after cell lysis, resulting in lower cell growth and yield. Bead-to-bead transfer was not tested for the macrocarriers because it is not feasible to add more macrocarriers in a fixed-bed bioreactor.

Our experiments in small-scale productions showed promising results with microcarrier Cytodex ${ }^{\circledR} 1$. Therefore, upscaling in a continuous stirred-tank reactor or wave-mixed bioreactor with a cell culture bag seems feasible. Alternatively, the Fibra-Cel ${ }^{\circledR}$ or iCELLis ${ }^{\circledR}$ macrocarriers showed a good production yield in suspension in Erlenmeyer flasks, but it was low in the Spinner flask. However, both macrocarriers are designed for fixed-bed bioreactors, in which a higher yield may be achieved.

Based on the compactness, high virus yield per batch, and ease of scalability of the iCELLis ${ }^{\circledR}$ system, further testing was done in iCELLis ${ }^{\circledR}$ nano bioreactor. The new medium exchange strategy tested in stationary culture was adapted for iCELLis ${ }^{\circledR}$ nano cultivation to reduce FBS content and seeding density. However, virus yield was lower than that in stationary controls and the Erlenmeyer flask. 
In summary, with the optimized cell culture medium VPSFM $^{\mathrm{TM}}$ and the new medium exchange strategy, we established a reduction in seeded cell density and FBS, leading to a FBS-free harvest, and tested carriers best suited for a high H-1PV yield, cell growth, and bead-to-bead transfer capability. We demonstrated feasible, carrier-based production and successfully scaled up the process from 24-well plates to Erlenmeyer and Spinner flasks. The combination of carrier cultivation with the new medium exchange strategy was tested in iCELLis ${ }^{\circledR}$ nano bioreactor, but further optimization to increase virus yield is required.

To produce oncolytic $\mathrm{H}-1 \mathrm{PV}$ for future patient application, the process needs to be transferred to a large-scale bioreactor for further upscaling. In addition to higher production capacity, critical process parameters (for example, dissolved oxygen, $\mathrm{pH}$ ) can be monitored and controlled using a bioreactor, resulting in increased reproducibility and product quality. Assuming that the yield generated in the Erlenmeyer flask can be upscaled for all carriers, the iCELLis ${ }^{\circledR} 500 \mathrm{~m}^{2}$ seems promising.

Supplementary Information The online version contains supplementary material available at https://doi.org/10.1007/s00253-021-11642-y.

Acknowledgements The authors wish to thank Hans-Jürgen Engel, Barbara Liebetrau, and Silvia Münstermann for the excellent experimental support. They also express great appreciation to Sherryl Sundell for editing the manuscript and Oryx $\mathrm{GmbH} \& \mathrm{Co} . \mathrm{KG}$ for funding.

Author contribution BL, DW, VF, MP, and MV conceived and designed the research. $\mathrm{AB}, \mathrm{DW}, \mathrm{VF}, \mathrm{MM}, \mathrm{MP}$, and MV conducted the experiments. $\mathrm{AB}, \mathrm{BL}, \mathrm{BL}, \mathrm{DW}, \mathrm{VF}, \mathrm{MP}$, and $\mathrm{MV}$ evaluated the data. BL, DW, and VF wrote the manuscript. All the authors read and approved the manuscript.

Funding Open Access funding enabled and organized by Projekt DEAL. This study was financially supported by Oryx GmbH \& Co.KG.

Data availability Not applicable.

Code availability Not applicable.

\section{Declarations}

Ethics approval This article does not contain any studies with human participants or animals performed by any of the authors.

Competing interests The authors declare no competing interests.

Open Access This article is licensed under a Creative Commons Attribution 4.0 International License, which permits use, sharing, adaptation, distribution and reproduction in any medium or format, as long as you give appropriate credit to the original author(s) and the source, provide a link to the Creative Commons licence, and indicate if changes were made. The images or other third party material in this article are included in the article's Creative Commons licence, unless indicated otherwise in a credit line to the material. If material is not included in the article's Creative Commons licence and your intended use is not permitted by statutory regulation or exceeds the permitted use, you will need to obtain permission directly from the copyright holder. To view a copy of this licence, visit http://creativecommons.org/licenses/by/4.0/.

\section{References}

Angelova AL, Aprahamian M, Balboni G, Delecluse HJ, Feederle R, Kiprianova I, Grekova SP, Galabov AS, Witzens-Harig M, Ho AD, Rommelaere J, Raykov Z (2009a) Oncolytic rat parvovirus $\mathrm{h}-1 \mathrm{pv}$, a candidate for the treatment of human lymphoma: in vitro and in vivo studies. Mol Ther 17(7):1164-1172. https://doi.org/ 10.1038/mt.2009.78

Angelova AL, Aprahamian M, Grekova SP, Hajri A, Leuchs B, Giese NA, Dinsart C, Herrmann A, Balboni G, Rommelaere J, Raykov Z (2009b) Improvement of gemcitabine-based therapy of pancreatic carcinoma by means of oncolytic parvovirus H-1PV. Clin Cancer Res 15(2):511-519. https://doi.org/10.1158/1078-0432. CCR-08-1088

Cotmore SF, Agbandje-McKenna M, Chiorini JA, Mukha DV, Pintel DJ, Qiu J, Soderlund-Venermo M, Tattersall P, Tijssen P, Gatherer D, Davison AJ (2014) The family Parvoviridae. Arch Virol 159(5):1239-1247. https://doi.org/10.1007/s00705-013-1914-1

Dupressoir T, Vanacker JM, Cornelis JJ, Duponchel N, Rommelaere J (1989) Inhibition by parvovirus H-1 of the formation of tumors in nude mice and colonies in vitro by transformed human mammary epithelial cells. Cancer Res 49(12):3203-3208

Faisst S, Guittard D, Benner A, Cesbron JY, Schlehofer JR, Rommelaere J, Dupressoir T (1998) Dose-dependent regression of HeLa cell-derived tumours in SCID mice after parvovirus H-1 infection. Int J Cancer 75(4):584-589. https://doi.org/10.1002/(sici)10970215(19980209)75:4\%3c584::aid-ijc15\%3e3.0.co;2-9

Fukuhara H, Ino Y, Todo T (2016) Oncolytic virus therapy: a new era of cancer treatment at dawn. Cancer Sci 107(10):1373-1379. https://doi.org/10.1111/cas.13027

Geletneky K, Hajda J, Angelova AL, Leuchs B, Capper D, Bartsch AJ, Neumann JO, Schoning T, Husing J, Beelte B, Kiprianova I, Roscher M, Bhat R, von Deimling A, Bruck W, Just A, Frehtman V, Lobhard S, Terletskaia-Ladwig E, Fry J, Jochims K, Daniel V, Krebs O, Dahm M, Huber B, Unterberg A, Rommelaere J (2017) Oncolytic H-1 parvovirus shows safety and signs of immunogenic activity in a first phase I/IIa glioblastoma trial. Mol Ther 25(12):2620-2634. https://doi.org/10.1016/j.ymthe.2017.08.016

Geletneky K, Huesing J, Rommelaere J, Schlehofer JR, Leuchs B, Dahm M, Krebs O, von Knebel DM, Huber B, Hajda J (2012) Phase I/IIa study of intratumoral/intracerebral or intravenous/ intracerebral administration of parvovirus H-1 (ParvOryx) in patients with progressive primary or recurrent glioblastoma multiforme: Parvoryx01 protocol. BMC Cancer 12:99. https://doi.org/ 10.1186/1471-2407-12-99

Geletneky K, Kiprianova I, Ayache A, Koch R, Herrero YCM, Deleu L, Sommer C, Thomas N, Rommelaere J, Schlehofer JR (2010) Regression of advanced rat and human gliomas by local or systemic treatment with oncolytic parvovirus $\mathrm{H}-1$ in rat models. Neuro Oncol 12(8):804-814. https://doi.org/10.1093/neuonc/ noq023

Hajda J, Leuchs B, Angelova AL, Frehtman V, Rommelaere J, Mertens M, Pilz M, Kieser M, Krebs O, Dahm M, Huber B, Engeland CE, Mavratzas A, Hohmann N, Schreiber J, Jager D, Halama N, Sedlaczek O, Gaida MM, Daniel V, Springfeld C, Ungerechts G (2021) Phase 2 trial of oncolytic H-1 parvovirus therapy shows safety and signs of immune system activation in patients with metastatic pancreatic ductal adenocarcinoma. Clin Cancer Res. https://doi.org/10.1158/1078-0432.CCR-21-1020 
Kestler J, Neeb B, Struyf S, Van Damme J, Cotmore SF, D'Abramo A, Tattersall P, Rommelaere J, Dinsart C, Cornelis JJ (1999) Cis requirements for the efficient production of recombinant DNA vectors based on autonomous parvoviruses. Hum Gene Ther 10(10):1619-1632. https://doi.org/10.1089/10430349950017626

Leuchs B, Frehtman V, Riese M, Muller M, Rommelaere J (2017) A novel scalable, robust downstream process for oncolytic rat parvovirus: isoelectric point-based elimination of empty particles. Appl Microbiol Biotechnol 101(8):3143-3152. https://doi.org/10. 1007/s00253-016-8071-x

Leuchs B, Roscher M, Muller M, Kurschner K, Rommelaere J (2016) Standardized large-scale $\mathrm{H}-1 \mathrm{PV}$ production process with efficient quality and quantity monitoring. J Virol Methods 229:48-59. https://doi.org/10.1016/j.jviromet.2015.11.022

Liu S, Ruban L, Wang Y, Zhou Y, Nesbeth DN (2017) Establishing elements of a synthetic biology platform for vaccinia virus production: biobrick design, serum-free virus production and microcarrier-based cultivation of cv-1 cells. Heliyon 3(2):e00238. https:// doi.org/10.1016/j.heliyon.2017.e00238

Martinez JAA, Milian JVF, Ueti MW, Rojas-Martinez C (2020) Innovative alternatives for continuous in vitro culture of babesia bigemina in medium free of components of animal origin. Pathogens 9(5):343. https://doi.org/10.3390/pathogens9050343

Moleirinho MG, Rosa S, Carrondo MJT, Silva RJS, Hagner-McWhirter A, Ahlen G, Lundgren M, Alves PM, Peixoto C (2018) Clinicalgrade oncolytic adenovirus purification using polysorbate 20 as an alternative for cell lysis. Curr Gene Ther 18(6):366-374. https:// doi.org/10.2174/1566523218666181109141257

Nuesch JP, Lacroix J, Marchini A, Rommelaere J (2012) Molecular pathways: rodent parvoviruses-mechanisms of oncolysis and prospects for clinical cancer treatment. Clin Cancer Res 18(13):35163523. https://doi.org/10.1158/1078-0432.CCR-11-2325

Rommelaere J, Geletneky K, Angelova AL, Daeffler L, Dinsart C, Kiprianova I, Schlehofer JR, Raykov Z (2010) Oncolytic parvoviruses as cancer therapeutics. Cytokine Growth Factor Rev 21(2-3):185-195. https://doi.org/10.1016/j.cytogfr.2010.02.011

Rourou S, van der Ark A, van der Velden T, Kallel H (2007) A microcarrier cell culture process for propagating rabies virus in vero cells grown in a stirred bioreactor under fully animal component free conditions. Vaccine 25(19):3879-3889. https://doi.org/10. 1016/j.vaccine.2007.01.086

Stewart B, Wild C (2014) World cancer report 2014. International Agency for Research on Cancer, Lyon, France

Tattersall P, Bratton J (1983) Reciprocal productive and restrictive virus-cell interactions of immunosuppressive and prototype strains of minute virus of mice. J Virol 46(3):944-955

Tree JA, Richardson C, Fooks AR, Clegg JC, Looby D (2001) Comparison of large-scale mammalian cell culture systems with egg culture for the production of influenza virus a vaccine strains. Vaccine 19(25-26):3444-3450. https://doi.org/10.1016/s0264410x(01)00053-6

van der Valk J, Bieback K, Buta C, Cochrane B, Dirks WG, Fu J, Hickman JJ, Hohensee C, Kolar R, Liebsch M, Pistollato F, Schulz M, Thieme D, Weber T, Wiest J, Winkler S, Gstraunthaler G (2018) Fetal bovine serum (FBS): past - present - future. Altex 35(1):99-118. https://doi.org/10.14573/altex.1705101

Wu SC, Huang GYL, Liu JH (2002) Production of retrovirus and adenovirus vectors for gene therapy: a comparative study using microcarrier and stationary cell culture. Biotechnol Prog 18(3):617-622. https://doi.org/10.1021/bp020026p

Publisher's note Springer Nature remains neutral with regard to jurisdictional claims in published maps and institutional affiliations. 